\title{
Information: The Foundation of Accountability
}

\section{Tony Harris}

\begin{abstract}
number of recent judgements by Australia's High Court and the Court of $A$ Appeal (Appeals Court) of the New South Wales (NSW) Supreme Court 1 have helped to improve our understanding, in our system of responsible government, of the relationship between the concepts of democracy, accountability and information. In many ways, those judgements merely confirm the commonsense view that parliament has a right to know what its government is doing. This makes more troublesome the views of some government ministers in NSW that access to information seems not to be important for accountability for the functioning of responsible government.

But while the parliaments of Australia now have a confirmed right to know what their governments are doing, the people of Australia do not yet have welldefined rights to know how their delegated powers and their resources are being used. Governments might agree that Australia has a representative system of government. They might also acknowledge that sovereign power rests in the people. But, outside of general elections and by-elections, governments and parliaments have not been able to develop an accountability regime which effectively recognises the sovereignty of the people. There is some recognition by the courts that the electorate needs information if it is to undertake its constitutional role effectively. But, notwithstanding our system of representative government, members of Australia's electorates have few effective rights to obtain information which they want. By comparison with some other democracies, there is in Australia a pressing need to recognise citizens' rights to know.
\end{abstract}

\section{Restrictions on Supplying Information}

Successive NSW governments have been less than generous in meeting the parliament's requests to access governmental information. In 1994 the then government did not wish to table the contractual arrangements between Sydney Water Corporation and the private sector companies which filtrate most of Sydney's bulk water supply. Because the government was in a minority in the Legislative Assembly, it was pressured to allow the documents to be viewed by members of the Assembly under restrictive conditions (Hansard, 1994).

Tony Harris was until recently the Auditor-General of New South Wales. He now writes for the Australian Financial Review. 
More recently, the NSW government argued that it was under no obligation to provide the Upper House, the Legislative Council, with any documents. The Legislative Council had asked to see documents concerning government's claims that its restructuring of public education entities had saved public moneys, documents about the government's initial decision not to allow gold mining at Lake Cowal, and a consultant's report to the government setting out the fair terms for Fox Studios to rent the former Sydney Agricultural Showground site (Hansard, 1995, 1996). A subsequent request by the Legislative Council to view Sydney Water documents concerning the 1998 'boil-water' controversy was similarly denied by the government (Hansard, 1998a).

The government's rejection of parliamentary requests for information is only the most visible sign of the desires of recent governments not to provide information on request. The NSW Deputy Ombudsman has identified the rates of high rejection by certain government departments of requests made under the State's freedom of information legislation. Entities associated with the Sydney Olympics 2000 and with the co-ordination of government activities (for example, the Premier's Department) were identified as meeting only a minority of requests for non-personal information (Deputy Ombudsman, 1999). An analogous finding has been made by the Commonwealth Ombudsman. In his recent report he has identified that Commonwealth agencies have been modifying their past approach to dealing with applications made under freedom of information legislation with the effect that a reducing proportion of applications are being met (Commonwealth Ombudsman, 1999).

The NSW government was particularly meagre in supplying information about the Sydney Olympics. Requests by the public to view the endorsement contract between the State and the Australian Olympic Committee and the principal or host city contract between the State and the International Olympic Committee were rejected, notwithstanding that their equivalent had been released by the Atlanta and Athens organising committees for their olympic games (NSW Auditor-General, 1998:3:1). The government claimed that these contracts were commercially confidential, as were all major contracts executed by the State. Indeed, the NSW government had received Parliament's approval to exempt these Olympics contracts from the application of the State's freedom of information legislation (Sydney Organising Committee for the Olympic Games Act 1983, s68).

As intimated earlier, the effectiveness of the State's freedom of information laws seems to be limited by agencies' practices. The Audit Office has seen examples of requests for information which plainly should have been met under law but were denied. Some were denied because Ministers would have been uncomfortable if they had been properly met; some were denied because other related information would ultimately be placed in the public domain; some concerning the salary of the Police Commissioner were rejected allegedly because of the Commissioner's privacy requests (NSW Auditor-General, 
1998:2:250, 1999:1:1). Each of these examples appears to be a clear breach of the freedom of information laws.

Of particular concern is the concept of commercial-in-confidence that has been applied mantra-like to government contracts with the private sector. Although in other non-Australian jurisdictions such contracts would be released to the public as a matter of course (Public Accounts Committee of NSW Parliament, 1994), Australian governments have found it convenient to extend their commercial intercourse with the private sector, while protecting those arrangements from scrutiny through claims of commercial confidentiality.

The NSW private sector initially supported the State's attempts to protect their dealings with the State Government from examination. In conducting the performance audit of agreements executed by the government for the privately owned M2 toll road, the Audit Office met significant barriers to information. Some private sector participants tried to class information as confidential even though it was included in the public prospectus for potential investors in the M2. Others tried to withhold information that had been provided to the United States Securities Exchange Commission and was accessible on the Internet. Yet others tried to prevent audit access to financial modelling documents which had been supplied on request to a member of the public (NSW Auditor-General, 1995).

This hard-line attitude by the private sector to the public's access to contractual information appears now to be waning. The Australian Olympic Committee voluntarily released information on the Sydney Olympics endorsement contract it has with the government and it subsequently made the entire contract public. At a recent private meeting with representatives of the State sector (including of The Audit Office of New South Wales), senior staff of major engineering and construction firms expressed the view that secrecy had harmed, not enhanced, their capacity to work with the government to meet public demand for facilities and services.

The Commonwealth Senate also is critical of government claims of commercial confidentiality. The reports of the Senate Standing Committee on Public Finance and Administration (1998) suggests that governments should not merely assert but should demonstrate any claims they make that documents cannot be released because of commercial-in-confidence issues. Similarly, the Australasian Council of Auditors-General (1997), in its submission on commercial-in-confidence matters to the Victorian Public Accounts and Estimates Committee, suggested that contracts once executed have little, if any, intellectual property which requires or deserves protection.

\section{Resolving the Parliamentary Impasse}

Even while the private sector was softening its former views on the commercialin-confidence content of executed contracts, the NSW government denied it had any obligation to provide requested documents to the Legislative Council and 
litigated the matter. The case was firstly considered by the NSW Appeals Court (Egan $v$ Willis, 1996, 40 NSWLR 650). To adjudge the matter, the Appeals Court firstly had to find, as it did, that the Legislative Council had such implied powers as are reasonably necessary for the proper exercise of the Council's functions.

The Court then examined those functions. The then Chief Justice observed that in the United Kingdom it is accepted that the legislature has the capacity to call for documents relevant to its duty to oversee the operations of the executive. In the United States of America, it is accepted that the Congress has the capacity to investigate matters to support its legislative function. The Chief Justice held that the same reasoning applies in New South Wales and that the Legislative Council's capacity to scrutinise the workings of executive government, by asking questions and demanding the production of State papers, is an important aspect of modern parliamentary democracy. It provides an essential safeguard against abuse of executive power'.

Notwithstanding that the Appeals Court unanimously held that the Legislative Council had the power to call for documents to support its legislative and accountability functions, the government appealed the judgement before the High Court of Australia. On the substance of the matter, the six sitting Justices of the High Court unanimously found against the government (Egan $v$ Willis, 1998, HCA 71). In doing so, the High Court expanded on some of the issues embedded in the NSW Chief Justice's observations about parliamentary democracy.

\section{Responsible government}

The leading judgement (Justices Gaudron, Gummow and Hayne) of the High Court in Egan $v$ Willis provides a contemporary legal view of the term responsible government. Quoting from an article on government accountability by Kinley (1995), their Honours advised that:

A system of responsible government has traditionally been considered to encompass 'the means by which Parliament brings the Executive to account' so that 'the Executive's primary responsibility in its prosecution of government is owed to Parliament'.

The leading judgement also referred to John Stuart Mill's 1861 work Considerations on Representative Government, that spoke of the task of the legislature 'to watch and control the government: to throw the light of publicity on its acts' and it reflected the views of the Queensland Electoral and Administrative Review Commission: 
whilst 'the primary role of Parliament is to pass laws, it also has important functions to question and criticise government on behalf of the people' and that 'to secure accountability of government activity is the very essence of responsible government'.

These observations, ranging from Mill's work to Kinley's 1995 article, are in a long line of consistently held views about the functions of parliament and parliamentarians in a system of responsible government. Thus the High Court of Australia in Horne v Barber (1920, 27 CLR 4) found that one of the duties of a member of parliament is:

that of watching on behalf of the general community the conduct of the Executive, of criticising it, and, if necessary, of calling it to account in the constitutional way by censure from his place in Parliament.

Bagehot (1867) in his History of the English Constitution saw the Executive as akin to a committee of parliament to which it is responsible for all of its activities.

In Egan $v$ Willis before the High Court, Justice McHugh appears to draw from this same tradition:

one of the most important functions of a House in a legislature under the Westminster system ... is the function of the Houses of Parliament to obtain information as to the state of affairs in their jurisdictions so that they can, where necessary, criticise the ways in which public affairs are being administered and public money is being spent.

In the same matter, Justice Kirby also placed the concept of responsible government in its wider context - as did Chief Justice Gleeson's Supreme Court judgement cited above — by finding that the New South Wales legislature:

is a component of a system of representative and responsible government established by the Australian Constitution for a free, independent, democratic and federal nation.

These observations accord with the common sense view about the relationships between the Executive and Parliament, a view embedded in Australian culture and tradition. On the matter of substance, Justice McHugh in his judgement came to the same conclusion albeit for different reasons. He found that the power of the Legislative Council to demand papers from a member who is a minister derives from the minister's special relationship with the Council: 
it is apparent that the power which (the Legislative Council) claims is one that inheres in the very notion of a parliamentary chamber which is a co-ordinate part of a legislature ....

Thus the High Court came to the fundamental view previously expounded by the NSW Appeals Court that under Australia's and New South Wales's system of responsible government, the Legislative Council has the power to demand State papers from a member who is a minister representing the government. What was not decided was whether there are any limitations to that power. This was a matter that was initially discussed between the Legislative Council and the government and was ultimately settled - unless there is a further appeal - by the NSW Appeals Court.

\section{Immunities and privileges}

On 13 October 1998, the Legislative Council of the NSW Parliament ordered the Leader of the Government to table all Sydney Water's documents relating to the ongoing contamination of the water supply. Although the order specified that documents subject to claims of legal professional privilege or public interest immunity would be handled separately from other documents, the government declined to present documents subject to these claims. Similar, but expanded orders made by the Council on subsequent dates were also not met by the government where the documents were subject to legal professional privilege or public immunity claims (Hansard, 1998b).

The subsequent hearing before the NSW Appeals Court is said to be the first occasion - either in Australia or the United Kingdom - where a court has been asked to decide on whether the government can decline to present material subject to claim of immunity or privilege. With respect to documents which are the subject of legal professional privilege claims, the Court concluded unanimously that the Legislative Council may have access to them for the performance of its functions (Egan v Chadwick \& Ors, 1999, NSWCA 176). Similarly, the Court held that the Legislative Council may require access to documents that are the subject of public interest immunity claims, even where the disclosure may harm the public interest.

However, the Court differed over the Legislative Council's powers to access a specific class of documents subject to public interest immunity claims, Cabinet documents. Justice Priestley considered that, just as the courts could demand access to Cabinet documents, so too could the Legislative Council, given its function and status in the system of government in New South Wales. Opposing this, Justice Meagher found that the Legislative Council has no power to demand access to Cabinet documents because such a power would subvert the doctrine of responsible government. The Chief Justice, somewhat in between, found that the Legislative Council's powers to call for Cabinet documents did not extend to 
Cabinet documents where that access would be inconsistent with the doctrine of collective ministerial responsibility. In particular, a power to access Cabinet documents which reveal 'the actual deliberations of Cabinet (would be) inconsistent with the doctrine...'. Although its basis is understandable, in many respects this is an unsatisfactory conclusion.

Justice Meagher held that the immunity of Cabinet documents from production is complete because the Legislative Council could not compel their production without subverting the doctrine of responsible government. The concept of Cabinet solidarity or collective responsibility - said to be inherent in the system of responsible government - derives from the claimed necessary benefits which are gained when ministers forming Cabinet are able to present a unified position on a matter. And as Chief Justice Spigelman observed, the 'principle of responsible government - in both dimensions of individual responsibility and collective responsibility - is part of the Constitution of New South Wales', notwithstanding that the principle has not always been observed.

But the conclusion which exempts certain or all Cabinet documents from Legislative Council scrutiny is, from a number of viewpoints, inherently unstable. Importantly, the Court's decision allows - perhaps incites - the executive to manipulate the production of Cabinet documents in an attempt to ensure that none would be liable for production to the Legislative Council. It is also unclear what the judgement actually means. Chief Justice Spigelman describes documents which reveal 'actual deliberations of Cabinet' as an example of those which the Legislative Council may not require. This has been translated by government, in the first test of this matter, as documents 'which relate to the deliberations of Cabinet' (Director-General of NSW Premier's Department, 1999).

The judgement leads to the unwanted prospect that the courts will be enmeshed in examining Cabinet documents one by one to determine whether their production to the Legislative Council would breach the doctrine of responsible government. How comfortable will the courts be in placing their opinions above those of one or more of the parliamentary chambers? Its impact is particularly curious when a government is in minority in the lower house of the NSW Parliament, the Legislative Assembly. May the majority validly require the executive to produce Cabinet documents that the Court would hold to be immune from production? Would a government produce its Cabinet documents in preference to loss of commission? Can a government lose commission by resisting to do what the law says it need not do?

The judgement appears to place the courts in a position superior to the parliament in the performance of their respective duties, if the former has access to documents that the latter has no power to demand. There is no doubt that courts must, as the occasion requires, have access to Cabinet documents, for example, to protect the rights of individuals against the adverse action of an executive. It can also be envisaged, under admittedly extreme or unlikely 
circumstances (such as in the recent perjury case against Dr Carmen Lawrence, a former Premier of Western Australia), that the courts should have access to any records or testimony of Cabinet's deliberations, such as contemporary verbatim records, if the occasion warrants that access.

The Court's decision is also unsatisfactory when viewed against practice. The relative openness of the deliberations of the Commonwealth Cabinet has not caused a failure of responsible government there compared to a much more secretive NSW government. And although Justice Meagher states that in the realms of Cabinet documents there is no room for holding that time will wither them', the indifference greeting the annual release by the Commonwealth Government of the bulk of Cabinet documents, which have passed their thirtyyear protected status, shows that the import of most of those released documents has indeed withered away.

The decision allows Cabinet Ministers to assert one view publicly while advancing a differing view in Cabinet, without having to be accountable for that private view. This practice is not, of course, unheard of.

The Chief Justice's judgement anticipated this criticism when he observed that the principle of Cabinet solidarity and its relationship to responsible government should be maintained, notwithstanding that it was more breached than honoured by Cabinet Ministers. But that plea does not seem reasonable if, by practice and convention, there are multiple exceptions to the rule. Allowing some Cabinet documents to be exempt from parliamentary scrutiny effectively allows governments the means to circumvent accountability, if they wish to avail themselves of it.

Notwithstanding these substantial reservations, the decision of the NSW Appeals Court has given some impetus to restoring the relationship between the parliament and its executive to one more closely envisaged by the NSW system of responsible government. That decision is unlikely, however, to be the last chapter in the historic tussle between the executive and the parliament. Even if the NSW government does not seek leave to appeal the matter before the High Court, other cases relevant to that tussle will inevitably arise.

\section{Commercial-in-confidence}

Perhaps the most satisfying aspect of the NSW Appeals Court decision is the short shrift given to the government's arguments for protection of documents, other than Cabinet documents, that are the subject of claims of public interest immunity. As noted earlier, NSW governments have often made claims that documents could not be released to parliament or the public because of their commercial-in-confidence characteristics. This was not accepted by the Appeals Court. Commercial-in-confidence was not seen by the Court as a criterion relevant to a decision to grant immunity from production of a document. 


\section{Representative Government}

With respect to the concept of responsible government, there has been a more or less satisfactory outcome to the parliament's quest that the accountable executive must provide it with information. But the public's right to access government information within the system of representative government has yet to be resolved.

The use of the phrase representative government appears to refer to the situation where government is formed from the representatives of the electorate that are voted to office in a popular election. This concept was discussed in the 1993 article on 'Public Trust and Public Accountability' by then Professor, now Justice, Paul Finn. He noted, echoing 'observations of justices of the High Court of Australia', that 'Sovereign power resides in the people' and that 'those entrusted with public power are accountable to the public for the exercise of their trust' (p. 52).

In the High Court case Egan $v$ Willis, cited earlier, Justice Kirby offered the useful expression of the concept of representative government when he found that the Legislative Council of NSW Parliament has the function of "rendering the Executive Government accountable, through it, to the Parliament and thus to the electors of the State'. He continued:

It is by such scrutiny that the system of government established by the Constitution Act 1902 and envisaged by the Australian Constitution permits effective public debate, facilitates the democratic choice of members of the chambers and allows periodic judgement of the government by the electors.

In the November 1996 judgement of the Appeals Court cited earlier, Chief Justice Gleeson found that:

At the present time New South Wales has a responsible and representative system of government with a Legislature comprising the Queen, the Legislative Council, and the Legislative Assembly. The members of both Houses are popularly elected, although the methods of election, and terms of office of the members, are different.

But these extracts give no particular comfort about how, apart from general elections or by-elections, governments are accountable to the public or about whether the electorate has any inherent right to State information it needs to perform its constitutional function to elect representatives to parliament. At one level, it is easy to advance the proposition that the people empower government and fund government activity and thus have some direct right to access 
government information, a right distinct from any concessions which parliament might allow through freedom of information legislation.

Perhaps a more sophisticated proposition, advanced in Finn (1993), is that the executive arm of government acts as trustee of assets and powers that belong to taxpayers collectively. Just as beneficiaries have the right in private law to access documents that are in the control of the trustee ${ }^{1}$, so the taxpayers have a right to access documents under the control of government.

\section{Citizen entitlements to information}

Australian Parliaments and governments have, in all or nearly all jurisdictions, given some recognition to the role of citizens in our system of representative government by allowing freedom of information legislation. Although this is not the place to review the efficacy of that legislation, it is worth observing that these entitlements are not always robust.

The Commonwealth Ombudsman (1999) recently reported that some agencies (particularly those dealing with governmental rather than personal information) were not as supportive of the philosophy of open government and freedom of information as they should have been. In some agencies the conflict between 'the old 'secrecy regime' and the new culture of openness' had not been resolved. Some agencies dealt with requests for information as legalistic, adversarial contests.

There is no reason to think that the situation in NSW is better than that found in the Commonwealth. For several reasons, including the more recent introduction of freedom of information legislation in NSW and the absence until recently of an administrative appeals body, it is likely to be worse. Certainly the Audit Office of NSW continually receives complaints from members of the public who have been refused access by the Government to information that is important to them. The type of information that has been denied relates to matters such as major contracts, proposed roads, development of heritage properties and a myriad of other interactions between the government and residents.

Not having access to relevant government information is likely to be particularly galling to many voluntary groups of citizens whose members have joined together because of their alarm about proposed government action and its possible adverse effect on them as local residents, citizens or taxpayers. In our contemporary culture, those groups often expend considerable effort to understand the issues of concern to them and often can draw upon the considerable capacity of professionals to assist their deliberations. It is understandable why the executive government might see them as a threat. It is

1 This matter was briefly discussed by Chief Justice Spigelman in Egan $v$ Chadwick \& Ors (1999) NSWCA 176 at 82. 
equally understandable how these groups could judge governments as being less than accountable when governments decline to provide them with State documentation relevant to their concerns.

An illustrative case is one heard by Judge Ainslie-Wallace of the NSW District Court when a representative resident of Port Kembla appealed against the decision of the Environment Protection Authority (EPA) to deny access to documents about the safety of emissions from the town's former copper smelter. In Helen Hamilton $v$ EPA (No. 367 of 1997) the court found that the Authority had established criteria for considering requests made under freedom of information legislation that were inconsistent with the law and had misapplied other criteria in deciding to refuse to provide many documents to the applicant.

The EPA failed, in its own judgement, to perform its statutory authority effectively with respect to protecting the environment. Because of that and because the issue was sensitive to the government which wished to re-establish the industry, the case is illustrative of how readily an authority can blithely refuse applicants' requests for information. Although the District Court provided the applicant with access to many of the documents previously withheld, it is instructive to see how information that should have been released in the public interest - because it concerned the health of local residents - was initially withheld by the government authority in the very same public interest.

\section{Parliament's Capacity to Inform the Public}

The newly articulated powers of the Legislative Council of the NSW Parliament to demand government documents is not likely to offer a full solution to this issue of citizens' rights to information. Parliament often sits in New South Wales for only fifty or so days a year, and it has no sizeable budget to support the activities of committees. Government plans to reduce the size of the Legislative Council, although now abandoned, would not improve the Council's capacity to debate issues of concern to the electorate. ${ }^{2}$

Auditors-General's reports to Parliament also have a limited capacity to respond to the many issues in which the parliament, the government and the public have expressed interest. For example, the Audit Office of NSW only has the capacity to issue about twelve reports a year on performance audits. Its Annual Report to Parliament has increased in size from 1,090 A5 pages in 1991 to over 1,600 A4 pages in 1998 and is probably about or beyond its useful limit. Producing larger reports would test the capacity of any reader.

Unless there is a changing attitude by parliaments or governments, community concerns about restricted access to information is not likely to

\footnotetext{
2 The Leader of the Government in the Legislative Council announced in June 1999 plans to develop a question for referendum which, if passed, would reduce the size of the Council and allow swift resolution to any Legislative Council action to amend legislation in a manner not acceptable to the Legislative Assembly.
} 
improve. It is thus encouraging to see that the courts, especially the High Court of Australia, are starting to link the concept of representative government to the capacity of the community to be allowed access to State documents.

\section{Judicial contributions}

Although the matter was heard before a single judge of the High Court and concerned the continuation of an injunction, rather than the substantive case, a 1980 judgement of Justice Mason offers some useful comment (The Commonwealth of Australia v John Fairfax \& Sons Ltd, 1980, 147 CLR 39). Fairfax wished to publish a book over much of the content of which the Commonwealth held copyright. The Commonwealth argued that there was a fundamental principle that publication of confidential material improperly obtained or imparted in confidence should not be published. The Commonwealth argued that, because the information was not public property, and because the law should be applied to government and private citizens alike, the court should continue to restrain publication, even if no public interest is served by maintaining confidentiality.

Justice Mason found that the legal principle upon which the Commonwealth sought to rely was to protect private interests:

not to protect the very different interests of the executive government. It acts, or is supposed to act, not according to standards of private interest, but in the public interest. ... It is unacceptable in our democratic society that there should be a restraint on the publication of information relating to government when the only vice of that information is that it enables the public to discuss, review and criticise government action.

The High Court thus determined the government's claim to confidentiality by reference to the public interest:

Unless disclosure is likely to injure the public interest, it will not be protected.

The court will not prevent the publication of information which merely throws light on the past workings of government, even if it be not public property, so long as it does not prejudice the community in other respects. The disclosure will itself serve the public interest in keeping the community informed and in promoting discussion of public affairs.

This, of course, does not help the public to obtain information. There is no hint in the judgement that laws making public servants or Auditors-General open 
to criminal prosecution for imparting government information without authority are invalid.

The issue of the public's right to know in a system of representative government was advanced in the unanimous High Court judgement on Lange $v$ Australian Broadcasting Corporation. This was a landmark case, not only because of the unanimity of the seven Justices, but because it allowed the High Court to re-examine and re-determine issues the court had considered in previous matters. The court held that:

Freedom of communication on matters of government and politics is an indispensable incident of the system of representative government which the Constitution creates.

If the freedom is to [be effective], it cannot be confined to the election period. Most of the matters necessary to enable 'the people' to make an informed choice will occur during the period between the holding of one, and the calling of the next, election. If the freedom to receive and disseminate information were confined to election periods, the electors would be deprived of the greater part of the information necessary to make an effective choice at the election.

The court also found, in an expression which was repeated in the High Court's leading judgement on the powers of the NSW Legislative Council, that the provisions of the Australian Constitution

which prescribe the system of responsible government necessarily imply a limitation on legislative and executive power to deny the electors and their representatives information concerning the conduct of the executive branch of government... .

\section{Citizens have no rights to information}

It is easy enough to understand the Court's warning that this freedom to receive and disseminate information 'is not absolute'. It is more difficult, however, to digest the court's view that the relevant sections of the Constitution 'do not confer personal rights on individuals'. In the court's view these freedoms give some immunity to the citizen from being adversely affected by laws or powers 'rather than a 'right' in the strict sense'.

In a later discussion which distinguishes the Australian Constitution from that of the United States where there is a Bill of Rights, the High Court states that the former: 
contains no express right of freedom of communication or expression. Within our legal system, communications are free only to the extent that they are left unburdened by laws that comply with the (Australian) Constitution.

This suggests that where a person's freedom to communicate has been improperly impinged, to achieve relief, the person has to show that the law is unreasonable for its purpose or that its purpose is incompatible with the constitutionally prescribed system of representative and responsible government.

In brief, it seems that although parliament has a right to know, the people have yet no such right. Citizens have a right to communicate and to receive information concerning their constitutional rights to vote. But, as yet, there appears to be no sound basis to require governments to inform the electorate on matters vital to the electorate other than through statute or through the exertions of parliament.

\section{Are parliaments' rights enough?}

This might have been an acceptable paradigm for those crafting the State and Federal Constitutions at the turn of the twentieth century. But the advent of the party system, with its often tight controls over the individuality of its parliamentary members, was not then visible. As noted by Justice Isaacs in Horne $v$ Barber (1920, 27 CLR 4), it would now be highly surprising if most government members of parliament thought, let alone agreed, that they had a duty to criticise their government.

There are many examples - in all Australian parliaments - where the executive government has used its party political powers to restrain the activities of fellow party members of parliament. Perhaps the most recent was reported by the media in June 1999 when the Prime Minister declared that no government member of the Senate would participate in any Senate inquiry into an activity of Justice Callinan of the High Court when he was in private practice.

There are many examples where the executive government has been able to exert its powers over parliament to restrain its activities. In 1995 the NSW Premier caused the Governor to prorogue parliament rather than allow the Legislative Council to debate a matter involving the Premier. In New South Wales, at least, the executive also effectively controls the parliament's funding and its brief sitting patterns.

Where the executive government holds such sway over non-executive members of parliament of the same party, where the executive effectively controls the deliberations of parliament, there is little comfort that parliament will be able to identify and to provide to the electorate information about the activity of the executive relevant to the electorate's needs. 
Perhaps as importantly, there is a need for a mechanism that allows the electorate to know what its parliament is doing. The document of the NSW Parliament that outlined all of the non-monetary benefits available to members of parliament was not a public document until 1998 when it was published by an independent, back-bench member of parliament.

\section{Informing the electorate}

If it is accepted that the public has difficulties in accessing information relevant to its duties as an elector, there is merit in exploring ways to improve that access.

As noted with respect to the High Court's judgement on Lange $v$ Australian Broadcasting Corporation that the absence of a Bill of Rights in Australia means that the electorate has no rights per se to require State documents. Thus one theoretical remedy is to agitate for such a bill. Those impatient for progress, however, should search elsewhere for a remedy.

It is possible to press for improvements in the laws that allow freedom of information or in the administration of those laws. Although the practical access to information allowed by law seems to vary from time to time, the involvement of the courts or appeal tribunals has helped to improve the electorate's access. As the Commonwealth Ombudsman seems to suggest, further improvements are possible.

The courts may also be able to apply the concept of trusts in public law as it has been applied in private law.

It is inherently appealing to describe holders of public offices as persons occupying a position of trust with the responsibilities of a trustee always to act in the best interests of the beneficiaries, the public. And, as already noted, the greater application of this concept in public law might allow improved access to information which is managed by the executive government but that belongs to the trust and the trust's beneficiaries.

But perhaps the most fruitful path currently available is to apply the dictum used by the High Court in Lange v Australian Broadcasting Corporation. If, as it says, there is a limit to the power of the executive and the government to withhold information from the electorate and its representatives, it is possible that some parts of the suite of legislation which already exists to limit the flow of information from the executive government to the electorate might be unconstitutional because they exceed the limits seen to exist by the High Court.

In an ideal world, governments would have responded to the unanimous, and repeated, views of the High Court by reviewing laws, such as the Commonwealth Crimes Act, which purport to make a crime of disclosing government information. The equivalent of this law exists in many, if not all, Australian jurisdictions. But there has been no evidence or sign that 
governments are investigating the constitutional validity of such statutory restrictions to communicate government information to the public.

In the absence of government action, it would be proper that our parliaments should investigate whether laws they enacted long ago can meet the High Court's newly-articulated tests of the Constitution. A parliamentary review can identify what restrictions are justified and what are not. That would be a significant parliamentary contribution to Australia's democracy.

\section{Conclusion}

There appears to be a convincing case that members of Australian electorates cannot exercise their constitutional right and duty without information relevant to their duty to elect representatives.

Although freedom of information legislation enacted by the parliaments of Australia has provided the public with some statutory entitlements since the 1970 s, those entitlements appear to be heavily circumscribed by inadequacies in the law or in the implementation of the law by the executive governments.

From time to time, even the parliaments of Australia have been refused access to documents of the executive government. But the recent, sustained refusal by the NSW government to table documents in, and otherwise provide documents to, the Legislative Council has resulted in High Court and NSW Appeals Court orders which recognise the rights of parliament in a system of responsible government to demand information from the government.

The judgements of the High Court also give some recognition to the electorate's need for information in a system of representative government, if the electorate is to exercise its duty in an informed way.

But the High Court has not yet discovered that the electorate has any rights to information, notwithstanding that 'the people are sovereign'.

Unless parliaments assert their newly identified rights vigorously, which is not likely given the power of the executive, the current law and practice will not allow the community access to information which it requires. Without that information, the electorate cannot exercise its obligation to vote in an informed way.

Thus, for the public to be properly informed, there may be a need for other mechanisms. One such is a bill of rights. Another is to agitate for improvements in the laws allowing freedom of information and in their administration. Yet another is an increased recognition by the courts that the public, as beneficiaries of the trust which governments manage, have the full rights of beneficiaries to access government information.

But an option which allows early and important gains is a review of the constitutional validity of Federal, State and Territory legislation restricting the flow of information from the executive government to the electorate. Parliaments are well placed to undertake such reviews. 


\section{References}

Australasian Council of Auditors-General (1997), Submission to the Inquiry into Commercial Confidentiality and The Public Interest, www.vicnet.net.au/ Yvicaud1/acag/achome.htm, July.

Bagehot, W. (1867), The English Constitution, Fontana Library, 1963 edition, London.

Commonwealth Ombudsman (1999), Report on Investigation of FOI in Commonwealth Agencies, Canberra, June.

Wheeler, C. Deputy Ombudsman, New South Wales (1999), Public Sector Compliance With FOI in New South Wales at Public Interest Advocacy Centre Conference, Sydney, 10 February.

Director-General of the NSW Premier's Department (1999), Memorandum to all Chief Executives, Sydney, 23 June.

Finn, P. (1993), 'Public Trust and Public Accountability', Australian Quarterly 65(2):50-9.

Hansard of Legislative Assembly of New South Wales Parliament (1994), 17 March.

Hansard of Legislative Assembly of New South Wales Parliament (1995), 26 October.

Hansard of Legislative Assembly of New South Wales Parliament (1996), 23 April.

Hansard of Legislative Assembly of New South Wales Parliament (1998a), 13 October.

Hansard of Legislative Assembly of New South Wales Parliament (1998b), 24 November.

Kinley D. (1995), 'Governmental Accountability in Australia and the United Kingdom: A Conceptual Analysis of the Role of Non-Parliamentary Institutions and Devices', University of New South Wales Law Journal 18(2):409 and 411.

Mill, J. S. (1861), Considerations on Representative Democracy, Parker, son and Bourn, London.

NSW Auditor-General (1995), Roads and Traffic Authority: The M2 Motorway, Performance Audit Report, Sydney, 31 January.

NSW Auditor-General (1998), Report to Parliament, Sydney.

Public Accounts Committee of NSW Parliament (1994), Proceedings of the Conference on Risk and Return: Traditional and Innovative Financing for Infrastructure Projects, Report No. 77, January.

Senate Standing Committee on Public Finance and Administration (1998), Contracting Out of Government Services, Second Report, May.

My thanks to two anonymous referees for helpful comments on an earlier draft of this article. 